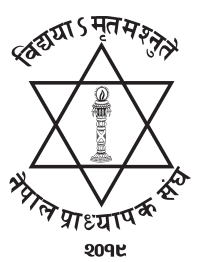

NJ: NUTA

\title{
Eco-friendly Methods of Natural Dye Extraction from Bark of Ficus religiosa and Their Impacts on Dyeing Technology in Nepal
}

\author{
Durga Prasad Pandey ${ }^{1}$, Numkant Parajuli ${ }^{1,2}$, Anil Devkota ${ }^{2}$, Sangam Aryal ${ }^{2}$ and Netra \\ Lal Bhandari*2 \\ ${ }^{1}$ Research Center for Applied Science and Technology (RECAST), Tribhuvan University, Nepal \\ ${ }^{2}$ Department of Chemistry, Tri-Chandra Multiple Campus, Tribhuvan University, Nepal \\ *Corresponding author Email: netra.tu.edu@gmail.com
}

\begin{abstract}
Plant-based natural dyes are eco-friendly and less allergic to the human body. Different reports on toxicity and allergic reactions that appeared in synthetic dyes cause interest in natural dyes in recent years. The present study focused on the feasibility of aqueous extraction of plant dyes from the bark of Ficus religiosa (Peepal), a historical tree of Hindu culture. Extracted dyes were characterized by ultra-violet visible (UV-Vis) spectroscopy and Fourier transform infrared (FTIR) spectroscopy to reveal the structural and functional confirmation of extracted dye. Dye was used for dyeing fabric using both natural and commercial mordant. Mordants such as lemon juice and metallic salts such as potassium dichromate $\left(\mathrm{K}_{2} \mathrm{Cr}_{2} \mathrm{O}_{7}\right)$, copper sulphate $\left(\mathrm{CuSO}_{4} .5 \mathrm{H}_{2} \mathrm{O}\right)$, and iron sulphate $\left(\mathrm{FeSO}_{4}\right)$ are used to set extracted dye on cotton fabrics and other fibers. This research aims to find the effectiveness and feasibility study of the use of natural mordant instead of metallic mordant. The use of natural dyeing with natural mordant is very effective for health purpose but found to be expensive.
\end{abstract}

Key words: Colorfastness, dyeing, mordant, natural dyes, ultraviolet-visible spectroscopy

\section{Introduction}

Natural dyes are emerging and superior alternatives compared to synthetic dyes for dyeing purposes from an environmental and health hazard point of view (Kanchana et al., 2013). In many of the world's developing countries, natural dyes can offer a not only rich and varied source of dyestuff, but also the possibility of an income through sustainable harvest and sale of these plants (Saravanan et al., 2012). Natural dyes from plant sources can be used for dyeing purposes as they are environment-friendly; for example, turmeric, the brightest of naturally occurring yellow dyes is a powerful antiseptic which revitalizes the skin, while indigo gives a cooling sensation (Grover \& Patni, 2011). Natural dyes have been a part of human life since time immemorial. With the production of synthetic dyes, about 175 years back, the use of natural dyes has witnessed diminished. During the last two decades, natural dyes have observed a process of revival with the increasing awareness of consumers for eco textiles (Saravanan et al., 2012) and environmental awareness.

NUTA JOURNAL, 7 (1 \& 2), 2020 : ISSN: 2616 - 017x 
Germany was the first to take initiative to ban numerous specific azo-dyes for their manufacturing and applications. Netherlands, India, and some other countries also followed the ban (Patel, 2011). Certain problems with the use of natural dyes in textile dyeing are color yield, compatibility of the dyeing process, reproducibility of results, limited shades, blending problems, and inadequate fastness properties (Sachan and Kapoor, 2007). These problems can be overcome by using chemicals called mordants. Mordants are metal salts that produce an affinity between the fabric and the dye (Samanta and Agarwal, 2009). Even though, many investigators have studied the feasibility of extraction of natural dyes from plants and their use in textiles industries, the scientific work on natural dyes extraction is very much limited (Bhandari, et al., 2020).

This research was performed with the explicit objective of extracting natural dye from bark of Ficus religiosa (Peepal) collected from Syangja district of Nepal using water as a solvent. It aims to investigate the comparative study of natural and synthetic dyeing effects on cotton clothes and other fabrics samples. The effect of natural mordants such as lemon juice and metallic salts as potassium dichromate $\left(\mathrm{K}_{2} \mathrm{CrO}_{7}\right)$, copper sulphate $\left(\mathrm{CuSO}_{4} .5 \mathrm{H}_{2} \mathrm{O}\right)$, and iron sulphate $\left(\mathrm{FeSO}_{4}\right)$, on the stability of the dye as well as on the color shade, was analyzed. Extracted dyes are analyzed by UV-Visible and IR spectroscopy instrumental analysis. The instrument analysis reveals the structural confirmation of natural dye collected from each dye (Ramprasath et al., 2017). The extraction showed bark of Ficus religiosa contains a brown red-colored dye that is feasible for extraction and dying by using standardized modern scientific techniques.

The use of non-toxic and eco-friendly natural dyes on textiles, wools, fabric, medicines as well in food items has become a matter of significant importance because of the increased environmental awareness to avoid some hazardous synthetic dyes (Bhandari, et al., 2021). Nepal is blessed with a large number of plants which exhibit dye properties and by extracting dyes from these plants we can use these dyes for different purpose like dyeing textiles, medicines, and other daily use materials. Also based on eco-friendly and non-toxic characteristics of natural dye, it can also introduce in solar cells especially in dye-sensitized solar cells (DSSC).

Materials and Methods

Ficus religiosa plant barks are collected from the Syangja district of Nepal. The dye was extracted in water and ethanol solvent by Soxhlet extraction method. The dyeing of cotton/synthetic fabric was carried out in three stages; extraction of dyes from the plant sources, mordanting, and dyeing. The original plant parts are shown in Figure 1. 

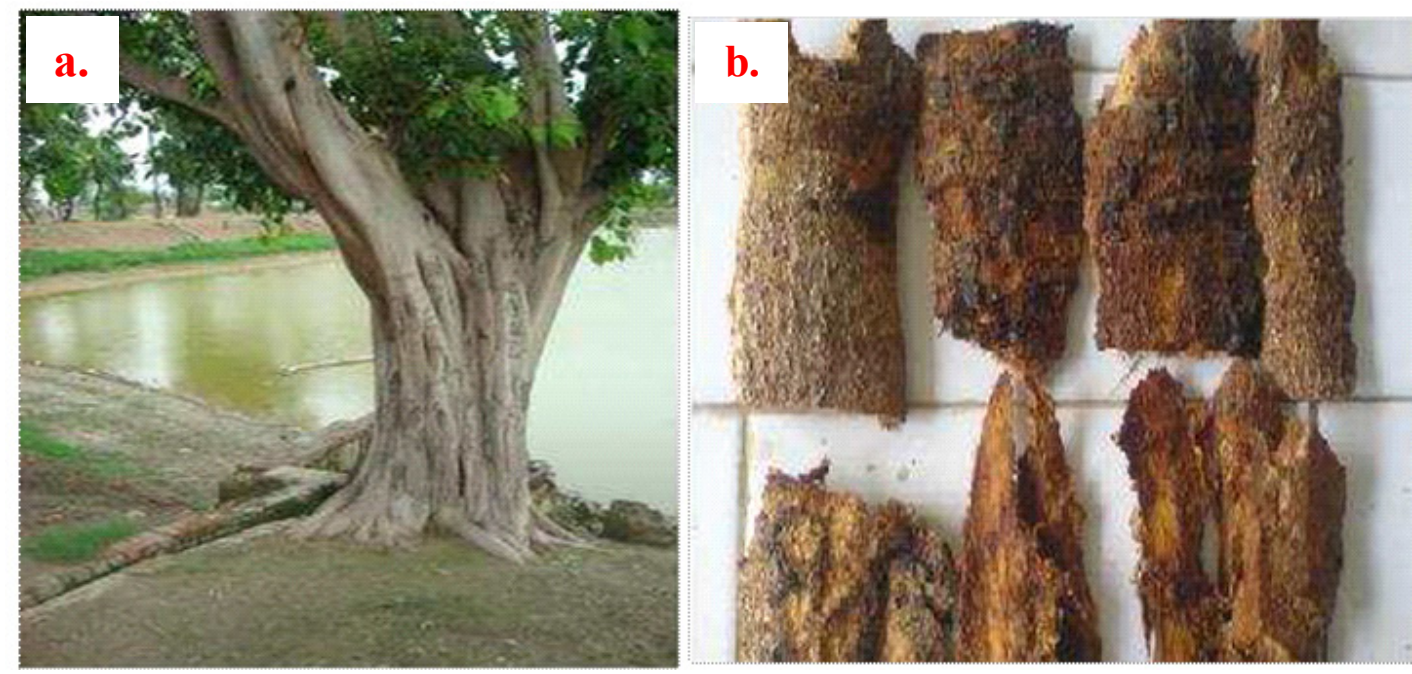

Figure 1: Photograph of Ficus religiosa (peepal) tree (a) and its bark (b) collected for dye extraction after grinding

The experiments were conducted for the maximum extraction of natural dye from bark of Ficus religiosa and others. The samples were collected and washed thoroughly with water to remove any dirt. After drying at room temperature, the samples were ground into a powder with the help of a grinder and the powdered samples were used for the extraction of dyes. To find the optimum conditions, experiments were conducted in aqueous extraction at various ranges of $\mathrm{pH}(2-8)$ and temperature (28 \pm $2{ }^{\circ} \mathrm{C}$ and $100{ }^{\circ} \mathrm{C}$ ) with an M:L ratio 1:10 (Tripathi et al., 2015).

For the dyeing purpose, cotton and synthetic fabrics were washed in a solution containing 2 $\mathrm{g} / \mathrm{L}$ commercials (Tide) detergent at $60^{\circ} \mathrm{C}$ for $25 \mathrm{~min}$, keeping the material to liquid ratio at 1:40. The scoured material was thoroughly washed with tap water and dried. The pieces of $7 \mathrm{~cm} \mathrm{x} 6 \mathrm{~cm}$ were cut and used for the experiments.

The metallic mordants such as potassium dichromate, ferrous sulphate \& copper sulphate were used and colorfastness was compared with natural mordant as lemon juice. The mordanting was carried out in three stages: pre-mordanting, simultaneous mordanting, and post-mordanting. Table 1 shows the different amounts of mordant used and details of mordanting time and temperature in dyeing. 
Table 1: The mordanting time and temperature of extracted dye for cotton and fabrics

\begin{tabular}{lllllll}
\hline Mordants & $\begin{array}{l}\text { Amount } \\
(\mathbf{g})\end{array}$ & $\begin{array}{l}\text { Distilled } \\
\text { water }(\mathbf{m L})\end{array}$ & $\begin{array}{l}\text { Water } \\
\text { temp } \\
\left({ }^{\circ} \mathbf{C}\right)\end{array}$ & $\begin{array}{l}\text { Boiling } \\
\text { time } \\
(\mathbf{m i n})\end{array}$ & $\begin{array}{l}\text { Mordanting } \\
\text { time }(\mathbf{m i n})\end{array}$ & $\begin{array}{l}\text { Mordanting } \\
\text { temp }\left({ }^{\circ} \mathbf{C}\right)\end{array}$ \\
\hline $\begin{array}{l}\text { Copper } \\
\text { mordant }\end{array}$ & 0.05 & 50 & 50 & 60 & 30 & $28-30$ \\
$\begin{array}{l}\text { Iron Mordant } \\
\text { Potassium }\end{array}$ & 0.19 & 50 & 60 & 60 & 30 & $28-30$ \\
$\begin{array}{l}\text { Mordant } \\
\text { Lemon juice }\end{array}$ & $2 \mathrm{~mL}$ & 50 & 90 & 60 & 30 & $28-30$ \\
\hline
\end{tabular}

Dyeing: The cotton and synthetic fabric used for dyeing was boiled in $\mathrm{NaOH}$ solution $(10 \%$ Wt./V) for 15 minutes to remove starch from cloth, washed with cold distilled water. This cloth was then transferred in mordants (Lemon, $\mathrm{K}_{2} \mathrm{CrO}_{7}, \mathrm{CuSO}_{4} .5 \mathrm{H}_{2} \mathrm{O}, \mathrm{FeSO}_{4}$ ) for 30 minutes followed by treatment in the dye bath for one hour as mentioned in table 1 . The effect of dye without mordent in fabrics was also studied. The different types of cotton cloth and synthetic fiber were experimented with for dyeing directly.

The extracted dye was characterized by ultraviolet-visible (UV-Vis) spectroscopy by Instrument Cary 60 at instrument version 2.00, $1 \mathrm{~g}$ of the dye was diluted in the $10 \mathrm{~mL}$ of methanol and Fourier transforms infrared (FTIR) spectroscopy using a Bruker Equinox 55 FTIR spectrometer in ATR mode at Nepal Academy of Science and Technology (NAST).

Results and Discussion

The crude sample and extracted dye sample of Ficus religiosa dye showed maxima at $282 \mathrm{~nm}$ and as shown in figure 2. The absorbance was found to be varied with different $\mathrm{pH}$ and with different mordants. Further, an increase in dye concentration with fixed mordant (potassium dichromate) also increases from $282 \mathrm{~nm}$ to $360 \mathrm{~nm}$. It means that the use of mordant not only improves the surface of fabric but also helps to increase the wavelength of maximum absorption as shown in Figure 2.

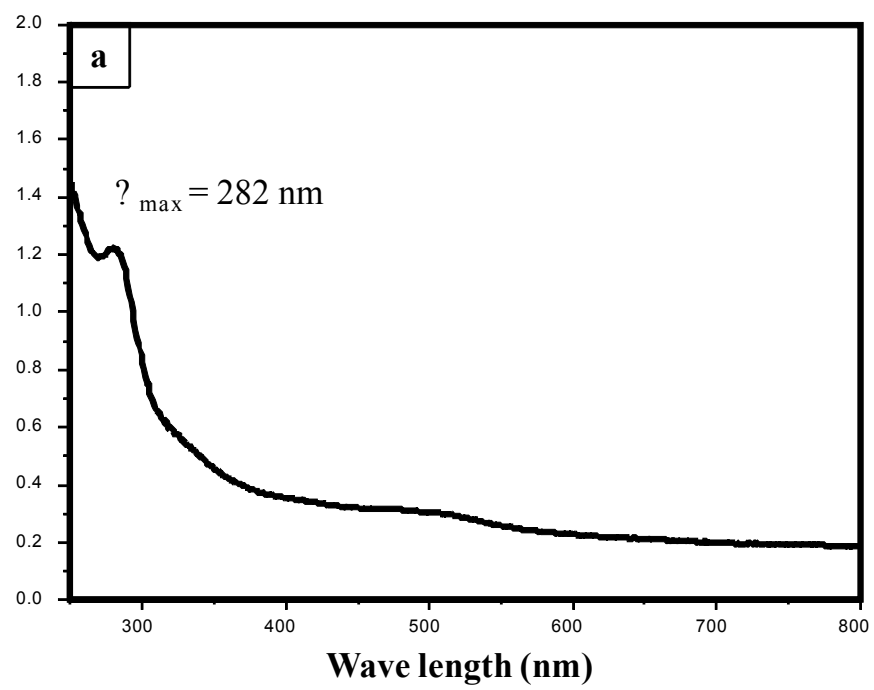

NUTA JOURNAL, 7 (1 \& 2), 2020 : ISSN: 2616 - 017x 


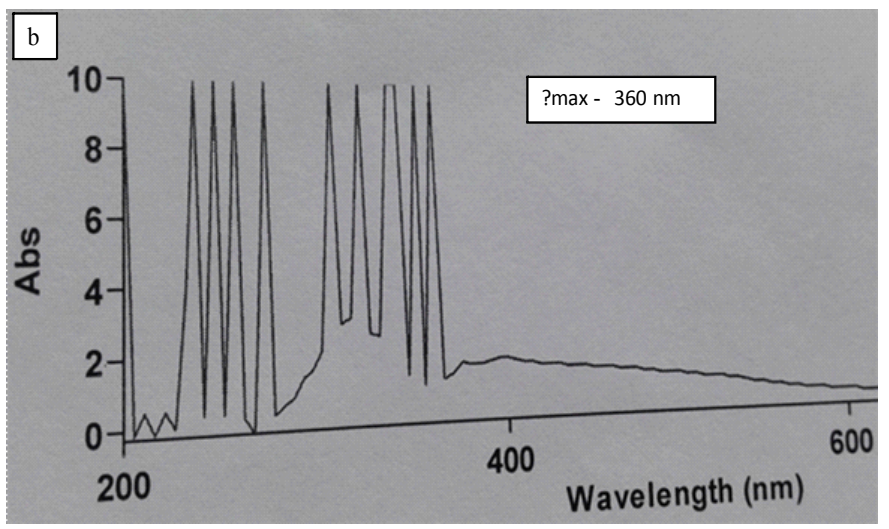

Figure 2: UV-Visible spectra of dye extract from Ficus religiosa a. Pure dye extract and b. Optimization of UV absorbance of dye with a fixed amount of potassium dichromate mordant (printed UV spectra).

Figure 3 is the FTIR spectra of a neat sample of Ficus religiosa and dye extract of Ficus religiosa. The main constituent of Ficus religiosa is the $\beta$-sitosteryl-D-glucoside. The strong signal of about $3250 \mathrm{~cm}^{-1}$ is due to stretching movements corresponding to a phenolic group - $\mathrm{OH}$. The peak at $2900 \mathrm{~cm}^{-1}$ is due to $\mathrm{C}-\mathrm{H}$ stretching, peak at $1610 \mathrm{~cm}^{-1}$ is due to the presence of absorption peak of aromatic $\mathrm{C}=\mathrm{C}$, Peak at $1380 \mathrm{~cm}^{-1}$ shows the presence of ethereal $-\mathrm{OCH}_{3}$ groups, peak at $1070 \mathrm{~cm}^{-1}$ is due to the presence of C-O-C pyranose ring of cycloalkane and ethereal groups. Further, peaks below $830 \mathrm{~cm}^{-1}$ (prominent at $600 \mathrm{~cm}^{-1}$ ) represent the presence of traces of heavy metals or the presence of $\mathrm{C}-\mathrm{H}$ bending of the $\mathrm{C}=\mathrm{C}-\mathrm{H}$ group present in the Ficus religiosa (Arora and Kaliya, 2013) and could not be explained in detail.

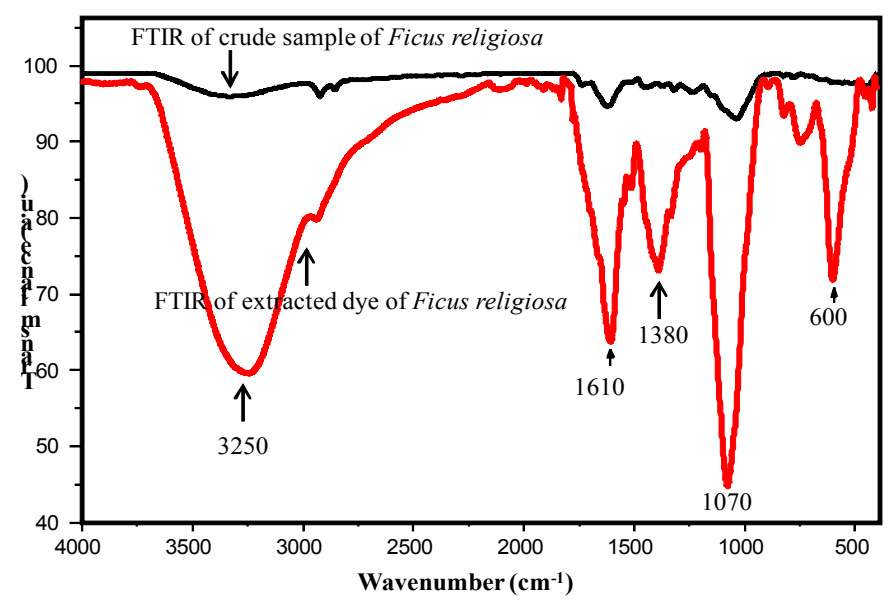

Figure 3: FTIR spectra of neat samples and extracted dye from bark of Ficus religiosa 
The different samples such as cotton and synthetic fibers were colored with different dyes by using mordant and without using mordant. The Natural dyes having limited substantively for the fiber, require the use of the mordant which enhances the fixation. Use of some auxiliaries like lemon juice as organic mordant was used. Figure 4 shows the dyeing on cotton cloth, banana fiber, and wool with Ficus religiosa dye and lemon juice as a mordant. The use of lemon juice as a mordant could not increase the intensity of color and light, wash and rub fastness properties but it was important because lemon juice also behaves as mordant.
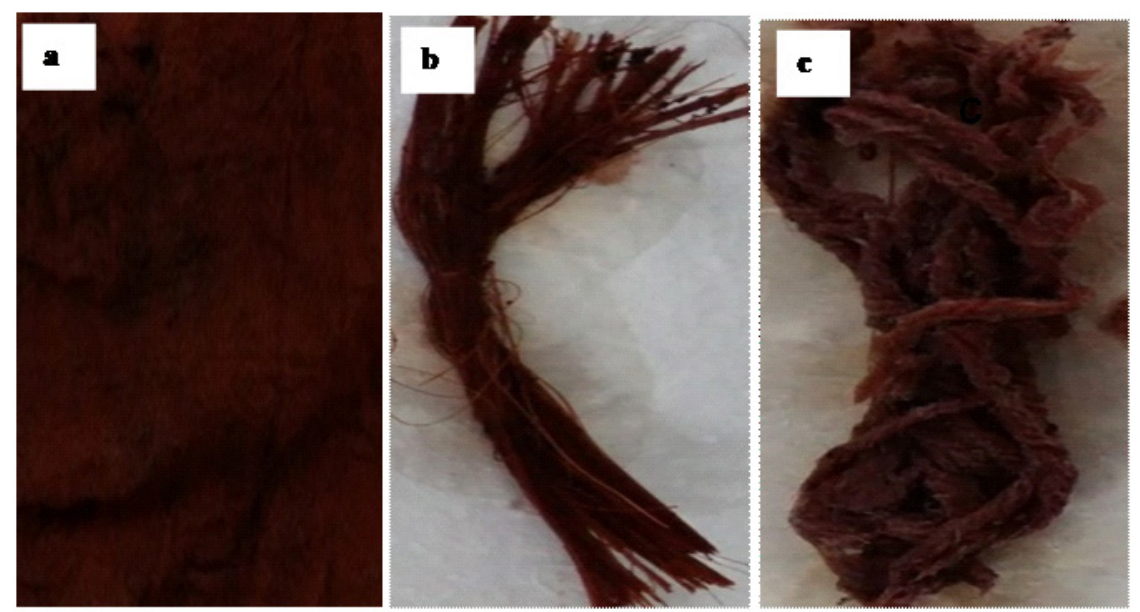

Figure 4: Photographs showing the dyeing of a) cotton cloth b) banana fiber and c) wool with dye extract from Ficus religiosa and lemon juice as mordant

Figure 5 shows the photographs of dyeing pure cotton, cotton cloth, banana fiber, and wool with Ficus religiosa dye extract using potassium dichromate as mordents. The use of this mordent increases the intensity of color and rub, wash and light fastness property.
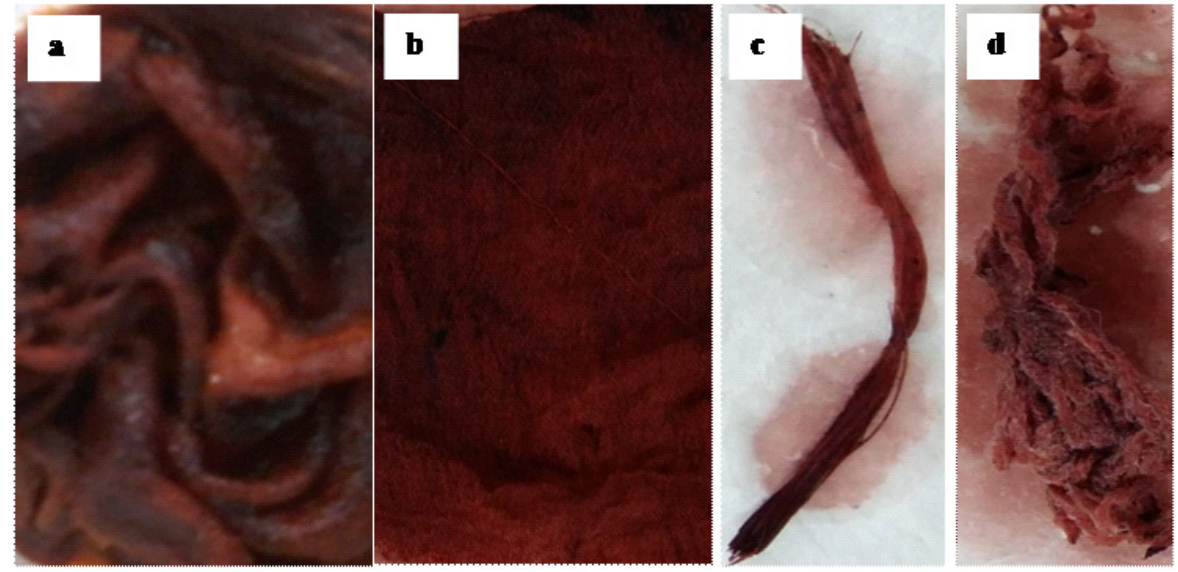

Figure 5: Photographs showing the dyeing process and dyeing of pure cotton, cotton cloths, banana fiber, and wool with Ficus religiosa dye and $\mathrm{K}_{2} \mathrm{Cr}_{2} \mathrm{O}_{7}$ as mordent 
Figure 6 shows the optical photographs of dyeing of cotton, banana fiber, and wool with Ficus religiosa dye with copper sulphate as a mordant. The color intensity of dye and rub, wash and light fastness property increases with the use of mordents. Results clearly show that commercial mordants are better for dying than natural mordants but one should be conscious of their environmental and human health impacts.
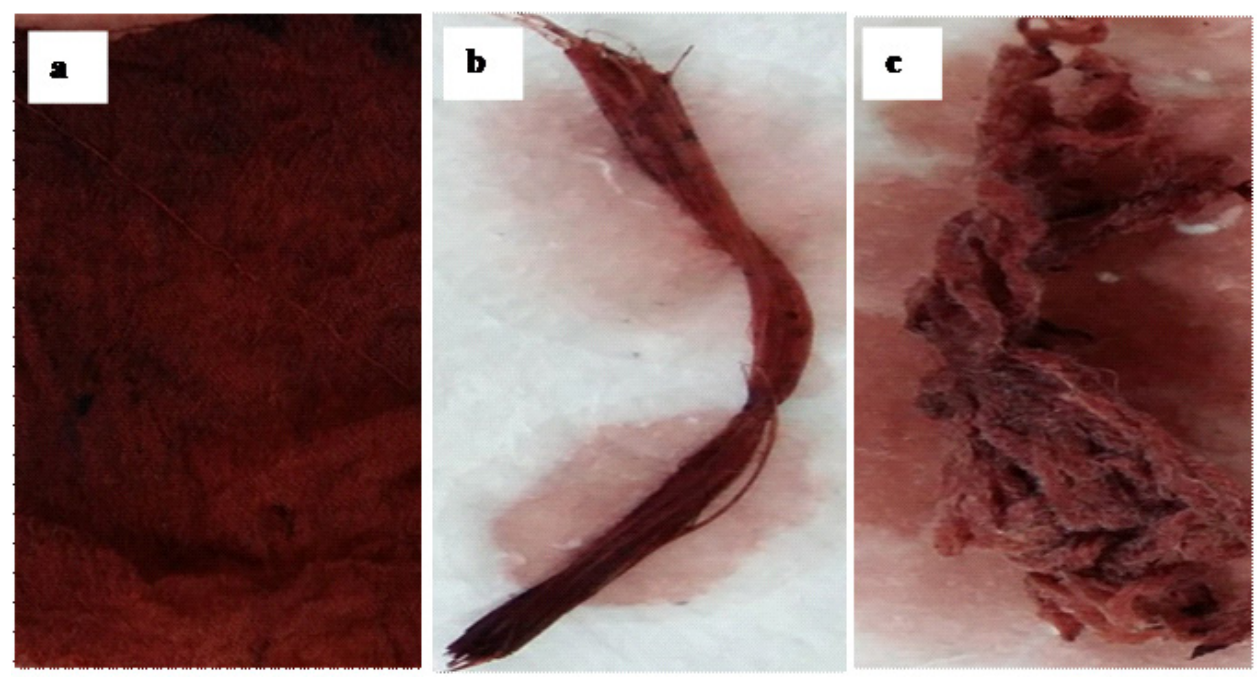

Figure 6: Photographs shows the dyeing of cotton, banana fiber, and wool with Ficus religiosa dye and $\mathrm{CuSO}_{4}$ as a mordant

\section{Natural Dyes and Dyeing Practices in Nepal}

Nepal is blessed with different varieties of flora and fauna so is an international hub for plantbased dyes. Although natural dyes are eco-friendly and safer for human health as compared to synthetic dyes, its commercialization has not been flourished in the country. One of the reasons behind is the low yield percent of natural dyes and other is very difficult to control the color shade on cotton and fabric. Mrs. Shanti Shrestha, at first established Kakani Himalaya Natural Dye Pvt. Ltd. at Kakani, Nuwakot as a first dye industry also searched online on the internet. This is a small-scale industry that follows old trends, equipment, and techniques for extraction of natural dyes and dyeing of fabrics, textiles which can be changed to the new scientific modern techniques to convert this small scale industry into large scale industry in national as well as international level. 

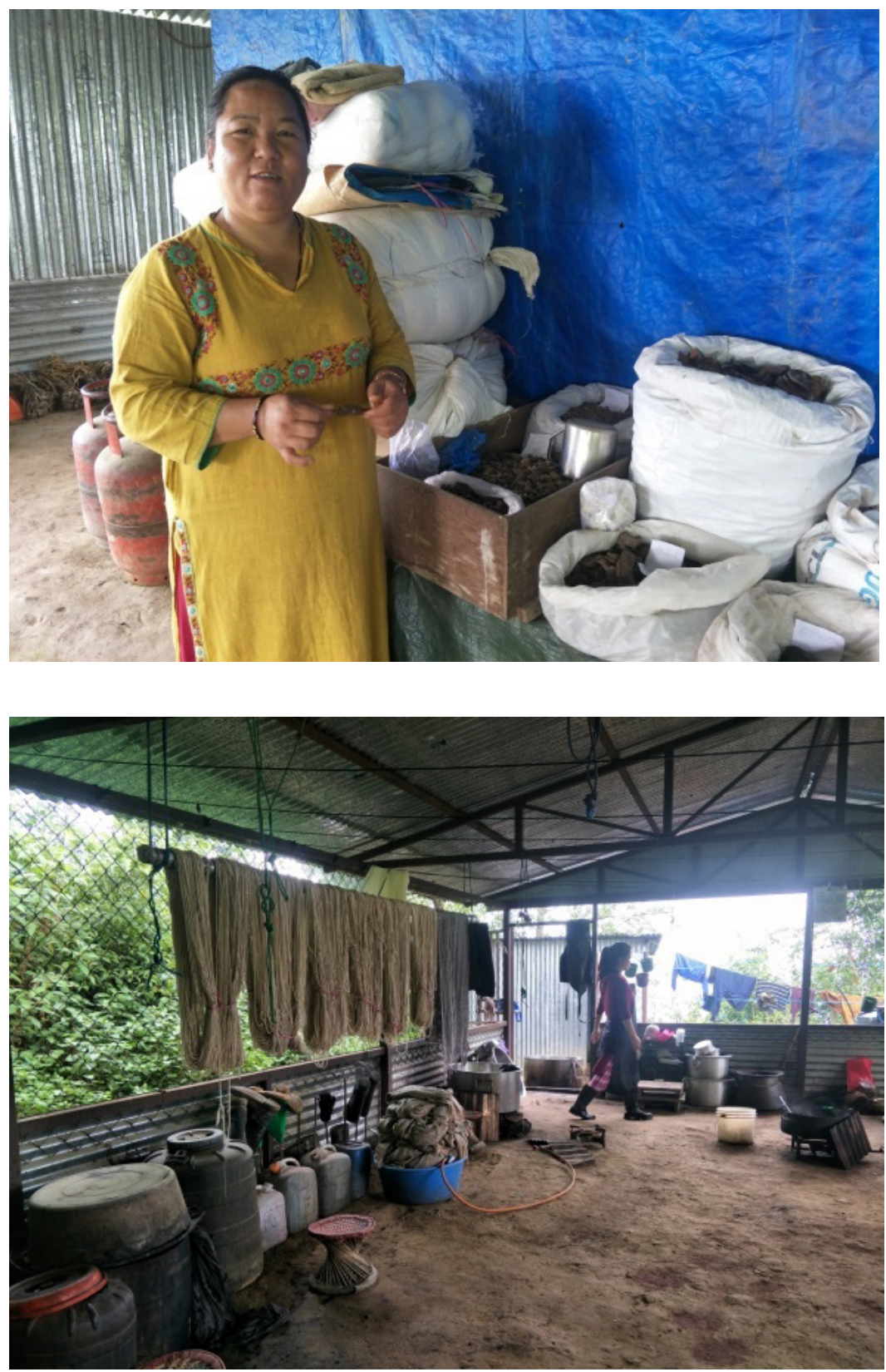

Figure 7: Mrs. Shrestha showing her working place explaining about dye sources, her co-workers, different fibers that were ready for dyeing as well as extraction process \& instruments used for dyeing 
Thus, this is a small practice that broads the importance of natural dyes for commercial purposes. This industry is based on dyeing techniques with the experience of Ms. Shanti on 28 different colors of which 12 are original and others are the secondary colors. There is a very urgent need for collaboration on the traditional dyeing industry with chemistry research so that the industry can flourish even in the international market. Therefore, if the proper research on natural dye will occur scientifically there is feasibility for the establishment of industrial areas related to products of natural dye in largescale industries.

\section{Conclusion}

Nepal is being rich in flora and fauna would be an international plant-based laboratory for natural dye and medicine. Natural dye has been extracted successfully from Ficus religiosa by using green solvents water and methanol. The dye is used for dyeing fabrics, cotton and wool by using natural and synthetic mordants. Lemon juice was also found to be an effective mordant but not as effective as that of synthetic mordants. Most natural dyeing industries in Nepal and other countries use to use synthetic mordants while dyeing and hence the dyeing process is not natural. This paper explores the idea of using lemon juice and chuck (concentrated lemon juice) as mordant. If more and more research has been done to explore the natural dyes and natural mordants then it would minimize the healthrelated allergic problems of dyes, and dyeing. The technology would be perfectly natural, green, and sustainable. There are many possibilities to establish small natural dyeing cottage industries at a local level that will help to uplift the economic condition of the society. The color of natural dye depends on many factors such as nature of color, source of color, $\mathrm{pH}$ of water, mordant type and concentrations, and so on. The use of natural dye is healthier but expensive so if the dye extraction and dyeing technology can be explored in large amount then the price would be reduced. The use of mordants increases the color intensity and washing, light, and rub fastness property of the dye. The application procedure is lengthy and complicated, thus cost and time for natural dyeing becomes expensive in comparison to synthetic dye but environmentally it would be benign.

\section{Acknowledgment}

Authors thank University Grants Commission (UGC) Nepal, Sanothimi, Bhaktapur for providing financial support to carry out this research in a proper way. Thanks also go to Chemistry Department, Tri-Chandra Campus and Research Center for Applied Science and Technology (RECAST), Tribhuvan University Kathmandu, Nepal for their laboratory facilities.

Conflict of Interest

There is no conflict of interest in this manuscript.

\section{References}

Arora, M., \& Kaliya, A. N. (2013). Isolation and characterization of stigmasterol and $\beta$-sitosterol-Dglycoside from ethanoic extract of the stems of Salvadora persica linn. International Journal of Pharmacy and Pharmaceutical Sciences, 5, 245-249.

Bhandari, N. L., Bist, K., Ghimire, J., Chaudhary, S., Pandey, D. P., \& Adhikari, R. (2020). Feasibility study of the Euphorbia pulcherrima plant extract as natural dye with different mordants for fabric dyeing. Journal of Institute of Science and Technology, 25(1), 30-36.

Bhandari, N. L., Ghimire, J., Shrestha, S., G. Bhandari, Bhattarai, S. R., \& Adhikari, R. (2021). Green 
extraction, characterization, applications and antimicrobial analysis of natural dye from Phyllanthus emblica. Asian Journal of Chemistry, 33(2), 404-410.

Grover, N., \& Patni, V. (2011). Extraction and application of natural dye preparations from the floral parts of Woodfordia fruticosa (Linn) Kurz. 2011. Indian Journal of Natural Products \& Resources, 2, 403-408.

Hye, M. A., Taher, M. Y., Ali, M. Y., Ali, M. U., \& Zaman, S. (2009). Isolation of catechin from Acacia catechu (cutch tree) by a convenient method. Journal of Scientific Research, 1, 300-305.

Kanchana, R., Fernandes, A., \& Bhat, B. (2013). Dyeing of textiles with natural dyes-an an eco-friendly approach. International Journal of Chemical Technology Research, 5, 2102-2109.

Kanhathaisong, S., Rattanaphani, S., Rattanaphani, V., \& Manyum, T. (2011). A spectroscopic investigation of the complex o Tumeric dye with copper(II) in an aqueous solution. Suranaree Journal Science and Technology, 18, 159-165.

Lal, C., Sharma, M. C., Shakyawar, D. B., Raja, A. S., Sharma, K. K., \& Pareek, P. K. (2011). Natural dye constituents from the rind of Punica grantum \& its application on pashmina fabrics. Scholar Research Library, 3, 350-357.

Arora, M., \& Kaliya, A. N. (2013). Isolation and characterization of stigmasterol and $\beta$-sitosterol-Dglycoside from ethanoic extract of the stems of Salvadora persica linn. International Journal of Pharmacy and Pharmaceutical Sciences, 5(1), 245-249.

Patel, N. K. (2011). Natural dye-based Sindoor. Life Sciences Leaflets, 11, 355-361.

Ramprasath, R., Kavi, G. G., \& Rathi, S. T. (2017). Isolation of natural dyes from Hibiscus rosasinensis and Marigold flower and dye properties of the dye on cotton cloth. IOSR Journal of Applied Chemistry (IOSR-JAC), 10, 74-79.

Roy, A., Lakshmi, T., \& Geetha, R. V. (2012). Estimation of quercetin in Acacia catechu ethanolic barks extracts by HPLC method. International Journal of Pharm Tech Research, 4, 501-505.

Sachan, K., \& Kapoor, V. P. (2007). Optimization of extraction and dyeing conditions for traditional turmeric dye. Indian Journal of Traditional Knowledge, 6, 270-278.

Samanta, A. K., \& Agarwal, P. (2009). Application of natural dyes on textiles. International Journal of Fiber and Textiles Research, 34, 384-399.

Saravanan, P., Chandramohan G., \& Saivaraj, S. (2012). A study on eco-friendly natural dye obtained from barks of Ficus religiosa on cotton fabric. World Journal of Applied Environmental Chemistry, 1, 30-34.

Tripathi, G., Yadav, M. K., Upadhyay, P., \& Mishra, S. (2015). Natural dyes with further aspects in the dyeing of textiles: A research article. International Journal of Pharma Tech Research, 8 , 96-100. 